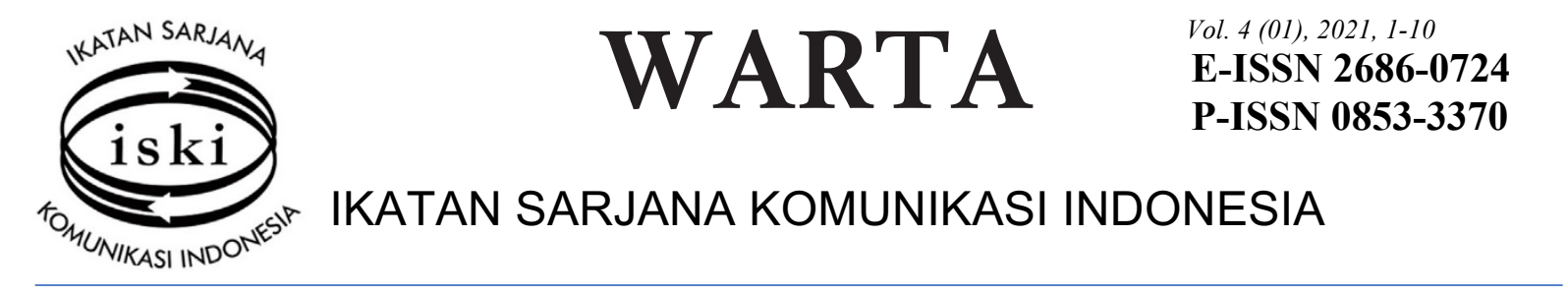

\title{
Implementasi Strategi Marketing Public Relations dalam Membangun Citra Batik untuk Generasi Muda
}

\author{
http://dx.doi.org/10.25008/wartaiski.v4i1.101 \\ Reza Yohanes $^{1 *}$, A.A Istri Putri Dwijayanti², Setyoningsih Subroto ${ }^{3}$ \\ ${ }^{1,2,3}$ Magister Ilmu Komunikasi, Institut Komunikasi dan Bisnis LSPR Jakarta, \\ Jl. K.H. Mas Mansyur Kav. No. 35, Jakarta 10220 - Indonesia \\ *e-mail korespondensi: 19211110208@1spr.edu
}

Submitted: 19/02/2021, Revised: 25/05/2021, Accepted: 09/06/2021

Accredited by Kemristekdikti No. 30/E/KPT/2019

\begin{abstract}
UNESCO recognizes Batik as Indonesia's culture. However, the younger's generation interest towards Batik continues to decrease significantly. In 2015, a premium batik brand called Negarawan, targeted towards the younger generation, arrived at the market. Negarawan implements marketing public relations strategy to build their brand image. Therefore, a research is needed to find out how Negarawan implements marketing public relations of three ways strategy in building their brand image for the younger generation. This research implements the qualitative approach using the study case methodology. The primary data collection is acquired through interviews and participatory observation. Whereas the secondary data collection is asquired through library studies and documentation. Key informants for the interviews were Negarawan's Chief Executive Officer and their Chief Marketing Officer as well as three of Negarawan's consumers. It is proven by the result of the research that Negarawan's marketing public relations implementation of three ways strategy supports the notion of building Negarawan brand image for the younger generation. Push strategy plays a role in boosting the sales, Pull acts as a reminder for community and consumer to participate, while Pass plays a role in forming positive opinion of the community.
\end{abstract}

Keywords: batik; brand image; case study; marketing public relations; Three Ways Strategy

Abstrak

Batik telah diakui oleh UNESCO sebagai warisan budaya dunia, namun ketertarikan generasi muda terhadap batik kian menurun. Di tengah keadaan ini, tahun 2015 muncul merek batik premium "Negarawan" dengan market generasi muda. Negarawan berkembang menjadi merek yang kuat dibuktikan dengan pengikutnya di Instagram hingga 24 ribu. Negarawan menggunakan strategi marketing public relations untuk membentuk citra merek. Penelitian ini menggunakan pendekatan kualitatif dengan metode penelitian studi kasus. Pengumpulan data primer dilakukan melalui wawancara dan observasi partisipatif. Data sekunder didapat melalui studi kepustakaan dan dokumentasi dan data primer diperoleh dari dua informan kunci Chief Executive Officer, Chief Marketing Officer dan tiga konsumen Negarawan. Hasil penelitian menunjukkan implementasi three ways strategy marketing public relations saling mendukung dalam membentuk citra merek. Push strategy berperan dalam mendorong penjualan, pull dalam meningkatkan partisipasi masyarakat dan konsumen, sementara pass dalam membentuk opini positif masyarakat.

Kata kunci: batik; citra merek; marketing public relations; studi kasus; three ways strategy

\section{PENDAHULUAN}

Batik merupakan kain yang digambar menggunakan cairan lilin yang dibuat setelah melalui proses panjang. Setiap proses memiliki esensi atas nilai-nilai masyarakat di dalamnya. Batik juga memiliki motif-motif tertentu. Dilihat dari aspek budaya, batik bukan hanya sekedar kain yang bermotif, tetapi dibalik motif-motif yang ada di batik, terdapat filosofi dan nilai kehidupan masyarakat di dalamnya. 
Dengan adanya perkembangan teknologi, batik ikut berkembang menjadi batik tulis, batik cap, serta batik cetak. Kain batik pun dapat dimanfaatkan menjadi beberapa produk seperti pakaian, tas, hiasan, dan lainnya. Batik dan motifnya inilah yang mencirikan keunikan batik Indonesia. Setiap gambar dan motif menceritakan sebuah kisah di dalamnya. Perpaduan warna dan gambar yang indah serta memiliki makna mendalam tertuang pada kain sutra maupun katun menarik perhatian banyak negara sehingga UNESCO menetapkan batik sebagai hasil karya warisan budaya dunia dari Indonesia pada tahun 2009 (ich.unesco.org, 2009).

Di tengah ketenaran batik Indonesia ternyata ketertarikan generasi muda terhadap batik mulai menurun, padahal batik sebagai sebuah produk budaya harus terus-menerus diturunkan dari generasi ke generasi. Jika anak muda tidak tertarik pada batik, bukan tidak mungkin batik pada suatu masa akan punah. Pemerintah telah melakukan sejumlah upaya untuk melestarikan batik, antara lain menerbitkan Surat Keputusan Presiden Republik Indonesia Nomor 33 Tahun 2009 tanggal 2 Oktober sebagai Hari Batik Nasional. Tanggal itu dipilih bertepatan dengan penetapan UNESCO yang menjadikan batik sebagai warisan dunia. Selain itu ada Keputusan Menteri Dalam Negeri Nomor 68 tahun 2015 yang menetapkan batik sebagai salah satu seragam kerja aparatur sipil negara. Pemerintah juga mendorong pengembangan industri batik rumahan.

Melihat dukungan pemerintah terhadap industri batik, perusahaan batik premium mulai berkembang dan memperluas kegiatannya, seperti Batik Keris, Batik Semar, Iwan Tirta Batik, Bateeq, Danar Hadi Batik, dan merek-merek premium lainnya. Mereka gencar melakukan promosi sekaligus mengenalkan batik premium secara luas. Meskipun ketertarikan anak muda terhadap batik terus menurun, terdapat satu merek premium yang berbeda dibandingkan dengan merek lainnya yaitu Batik Negarawan. Hal ini dapat dilihat dari perbedaan pemilihan target market antara Negarawan dengan merek-merek batik premium lainnya.

Negarawan didirikan tahun 2015 sebagai pendatang baru di industri batik premium, Negarawan hanya menyediakan batik tulis, batik cap serta batik tenun. Negarawan fokus menyediakan batik berkualitas dengan bahan dan model menarik. Negarawan memiliki keberanian mengambil pasar batik premium dengan harga yang tidak murah dan memilih generasi muda sebagai target market utama, meskipun pasar batik tulis sedang menurun dan ketertarikan anak muda terhadap batik juga menurun.

Sebagai sebuah start-up company, Negarawan berhasil menarik perhatian masyarakat dan media. Hal ini dapat dilihat dari banyaknya tulisan dari berbagai media seperti Kompas, Tribun, Liputan 6.com, dan Metro TV mengulas Negarawan dengan nada positif (Gambar 1).

\section{Fabelio-Negarawan luncurkan furnitur bermotif batik eksklusif}

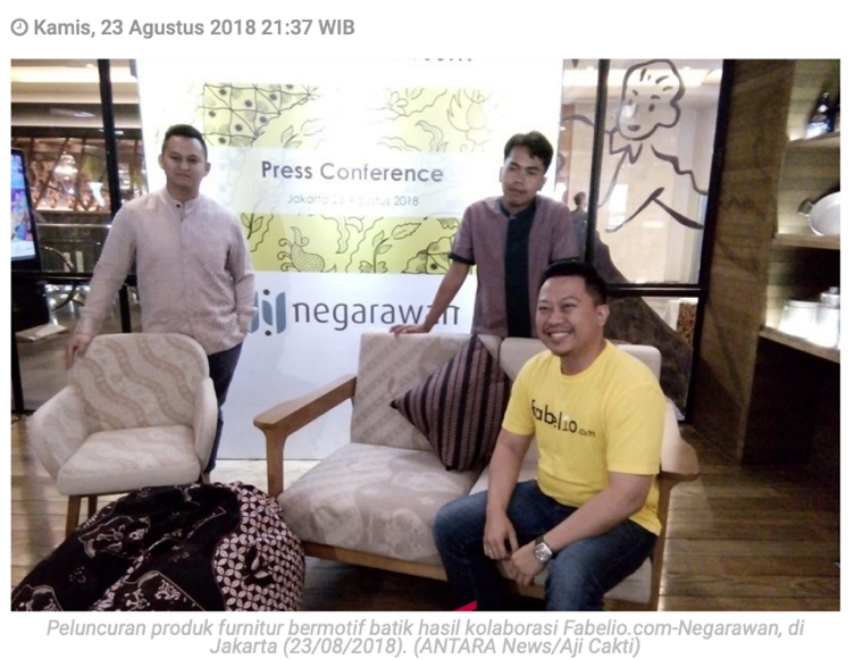

Jakarta (ANTARA News) - Batik sebagai salah satu warisan budaya Indonesia sering diidentikkan dengan pakem fashion, terutama baju dan sejenisnya, padahal batik bisa diaplikasikan lebih luas seperti apa yang dilakukan oleh Fabelio.com dan Negarawan.

Gambar 1. Contoh Publisitas Negarawan Sumber: Antaranews.com, 2018. 
Melalui keunikan dalam produk dan komunikasinya, Negarawan membangun citra merek yang baik di mata konsumen. Shimp (2010) menjelaskan citra merek merepresentasikan asosiasi yang muncul dalam ingatan konsumen saat mereka sedang memikirkan merek tertentu. Negarawan tidak hanya berusaha membangun citra merek yang positif, tetapi juga berusaha membangun citra merek yang spesifik yaitu batik untuk generasi muda, nyaman dan pas dikenakan dengan harga terjangkau. Jadi, ketika konsumen mengingat merek batik, maka mereka akan ingat Negarawan yang sesuai untuk dirinya serta memiliki kualitas baik. Jika Negarawan berhasil membangun citra merek yang positif dan spesifik, tentu ini akan menjadi keuntungan dalam bersaing melawan merek lainnya.

Menurut penelitian Fony Sanjaya dan Listyo Yuwanto (2017), faktor-faktor yang mendorong generasi muda tertarik menggunakan busana batik adalah nilai estetika, prestise, fashionable, identitas bangsa, dan fleksibilitas. Nilai estetika batik merupakan intensi utama memilih pakaian batik pada generasi muda. Hal inilah yang perlu diperhitungkan sebuah brand untuk mempromosikan batiknya bagi kalangan generasi muda (Sanjaya \& Yuwanto, 2017). Kemudian penelitian Yudhi Lim (2019) menunjukkan, batik tulis memiliki makna sosial sebagai integritas bangsa Indonesia dan patriotism. Hal ini bisa dijadikan sebagai konten komunikasi dalam membangun brand dengan generasi muda.

Sebagai merek yang menargetkan anak muda sebagai konsumen utama, Negarawan berusaha menciptakan kesan sebagai merek anak muda yang nasionalis. Secara konsisten brand itu menggunakan bahasa Indonesia dalam setiap unggahannya di Instagram. Negarawan menggunakan Instagram sebagai media untuk bercerita kepada setiap konsumennya mengenai nilai brand Negarawan.

Negarawan berupaya menjalankan strategi membangun citra merek yang positif dan kuat serta sesuai dengan keinginan perusahaan. Melalui citra merek yang kuat sebagai batik untuk generasi muda, citra merek ini dapat bersaing dengan kompetitor lainnya. Konsumen yang sudah membeli maupun konsumen potensial akan mengingat Negarawan karena berbeda dengan merek batik lainnya. Strategi yang dijalankan Negarawan adalah konsep Marketing Public Relations untuk membangun citra merek. Menurut Harris dan Whalen (2006), Marketing Public Relations adalah strategi dan taktik public relations untuk mencapai marketing objectives dari suatu merek.

Negarawan berusaha menjalankan berbagai strategi dan taktik promosi untuk membentuk citra merek yang positif sebagai batik untuk generasi muda. Langkah public relations juga kerap diambil Negawaran sebagai pendekatan strategis untuk mencapai tujuan pemasaran.

Terdapat beberapa penelitian terkait promosi batik untuk generasi muda, salah satunya adalah penelitian Shandy Oktavia Yusmarlia (2017) berjudul "Perancangan Promosi untuk Memperkenalkan Batik Betawi kepada Generasi Muda". Temuan penelitian ini adalah rancangan promosi untuk memperkenalkan batik dapat dilakukan melalui media online seperti situs interaktif. Hal sejalan juga dinyatakan oleh Muhammad Rizky (2018) dalam penelitian "Perancangan Digital Campaign sebagai Strategi Peningkatan Awareness terhadap Batik Betawi". Temuan penelitian ini, akun media sosial dan mengunggah konten secara konsisten, menarik, dapat meningkatkan awareness warga terhadap Batik.

Menurut penelitian Priyo Subekti, Hanny Hafiar, dan Kokom Komarian (2020) dengan judul "Word of Mouth sebagai Upaya Promosi Batik Sumedang oleh Perajin Batik (Studi Kasus pada Sanggar Batik Umimay)", word of mouth promotion lebih berdampak dalam segi penjualan. Para pembeli batik tulis yang notabene harganya lebih mahal dibandingkan batik cetak memiliki pengelaman langsung memakai batik sebagai fashion kemudian membagikan informasi pengalamannya itu ke jaringan sosial seperti keluarga, teman dan lingkungan pekerjaan.

Berbeda dengan ketiga penelitian sebelumnya, penelitian kami fokus pada strategi promosi marketing public relations secara keseluruhan. Bukan hanya melalui media sosial atau word of mouth tapi membahas seluruh strategi yang digunakan. Berdasarkan latar belakang tersebut, maka rumusan penelitian ini adalah: "Bagaimana pelaksanaan taktik three ways strategy (push, pull, pass) Marketing Public Relations Negarawan dalam membentuk citra merek untuk generasi muda di benak konsumen?".

Adapun tujuan penelitian ini adalah untuk mengetahui pelaksanaan taktik three ways strategy (push, pull, pass) Marketing Public Relations Negarawan dalam membentuk citra merek Negarawan untuk generasi muda. Dengan rumusan dan tujuan penelitian tersebut, maka penelitian ini berusaha menggambarkan secara menyeluruh langkah-langkah yang diambil Negarawan untuk membentuk citra mereknya sebagai batik untuk generasi muda. 


\section{KERANGKA TEORI}

Konsumen merupakan salah satu publik dari organisasi dan melalui hubungan yang baik dengan konsumen akan tercipta kepercayaan dan loyalitas konsumen sehingga konsumen akan memilih perusahaan atau organisasi tersebut. Dengan semakin berkembangnya ekonomi dan persaingan di dunia bisnis, orang-orang marketing menyadari potensi dari penggunaan public relations dalam melakukan pemasaran karena konsumen akan meningkatkan nilai perusahaan di mata konsumen. Hal tersebut didukung oleh Harris (1998) melalui pernyataannya "The relationship between public relations and marketing is growing stronger as marketers recognize the importance of building relationships between brands and consumers". Harris menambahkan pentingnya public relations dalam kegiatan branding yang dilakukan oleh orang- orang marketing yaitu:

Public relations is particularly effective in building brand equity because of its power to positively enhance the assets that add value to the brand. These assets include brand awareness, brand loyalty, perceived quality, and other brand associations that identify and differentiate the brand from other market choices.

Berdasarkan pernyataan tersebut dapat dipahami public relations sangat efektif dalam kegiatan branding karena public relations memiliki kekuatan serta nilai tambah bagi brand. Melalui public relations sebuah merek bisa meningkatkan kesadaran konsumen terhadap merek, loyalitas terhadap merek, serta berbagai asosiasi positif di pikiran konsumen yang dikaitkan dengan merek atau yang dapat disebut sebagai citra merek. Dengan kata lain melalui penerapan public relations dalam marketing yang pada akhirnya menciptakan suatu konsep marketing public relations dapat meningkatkan berbagai hal positif dari merek salah satunya citra merek.

Dalam menjalankan konsep marketing public relations, terdapat beberapa tujuan yang ingin dicapai oleh perusahaan. Secara sederhana menurut Harris (1998) sebagai orang yang pertama kali mencetuskan konsep marketing public relations, adalah mendukung tujuan marketing. Jika perusahaan dapat mencapai tujuan marketing melalui konsep marketing public relations maka tujuan dari corporate public relations juga dapat tercapai karena reputasi perusahaan menjadi baik di mata konsumen jika terjadi komunikasi yang konsisten dan mendukung keunggulan dari produk/jasa perusahaan atau organisasi. Sehingga dapat dikatakan melalui konsep marketing public relations akan terjadi sinergi dan tercapainya tujuan dari marketing serta corporate public relations (CPR).

Menunurut Harris dan Whalen (2006), tujuan utama marketing public relations, adalah mendapatkan dukungan dari pihak ketiga yang kredibel sehingga akan menciptakan "buzz" terhadap produk suatu perusahaan dan itu akan menciptakan asosiasi yang baik terhadap merek dalam persepsi konsumen. Dari pengertian tersebut dapat diketahui bahwa asosiasi baik terhadap merek di persepsi konsumen dapat terbentuk melalui proses marketing public relations. Asosiasi baik di persepsi konsumen merupakan citra merek dari suatu perusahaan. Dalam pernyataan ini juga memperlihatkan dengan jelas bahwa konsep marketing public relations erat hubungannya dengan teknologi seperti new media. Konsep marketing public relations (MPR) dijelaskan menggunakan berbagai sarana mencapai tujuannya, seperti new media, acara khusus, serta mengaitkan merek dengan isu sosial tertentu serta menunjukkan dukungannya terhadap isu sosial tersebut.

Konsep yang sebelumnya dirumuskan oleh Harris, kembali dijelaskan oleh Alifahmi (2008) dengan contoh penerapan teknik operasional yang dapat dilihat implementasinya pada kegiatan perusahan dari ketiga strategi ini agar lebih mudah dipahami (Tabel 1).

Tabel 1. Penerapan three ways strategy marketing public relations

\begin{tabular}{|c|c|c|c|}
\hline Strategi & Target/Sasaran & CPR/MPR & Penerapan \\
\hline Push strategy & $\begin{array}{l}\text { Sales Force } \\
\text { Dealer } \\
\text { Distributor } \\
\text { Pengecer }\end{array}$ & MPR & $\begin{array}{l}\text { Trade show/Expo } \\
\text { Publisitas } \\
\text { Penerbitan } \\
\text { Potongan harga }\end{array}$ \\
\hline Pull Strategy & $\begin{array}{ll}\text { Konsumen } & \text { atau } \\
\text { pemakai produk }\end{array}$ & MPR & $\begin{array}{l}\text { Media event/visit } \\
\text { Pameran } \\
\text { Sampling } \\
\text { Survei }\end{array}$ \\
\hline
\end{tabular}




\begin{tabular}{|c|c|c|}
\hline & & $\begin{array}{l}\text { Newsletter } \\
\text { Iklan } \\
\text { masyarakat }\end{array}$ \\
\hline Pass Startegy & $\begin{array}{lr}\text { Pembentukan } & \text { opini } \\
\text { Konsumen melalui } & \\
\text { pemerintah LSM/Key } & \text { CPR \& MPR } \\
\text { Opinion Leader } & \end{array}$ & $\begin{array}{l}\text { Memperhatikan isu } \\
\text { sosial } \\
\text { Aktivitas kepedulian } \\
\text { Komunikasi } \\
\text { Sponsor }\end{array}$ \\
\hline
\end{tabular}

Sumber: Alifahmi, 2008, h.78- 79

\section{METODE PENELITIAN}

Penelitian ini menggunakan pendekatan kualitatif, karena menurut Leavy (2017) pendekatan kualitatif cocok untuk penelitian sosial untuk memperoleh pemahaman secara holistik mengenai fenomena sosial yaitu implementasi marketing public relations yang tergambar dari berbagai kegiatan promosi Negarawan mengkomunikasikan mereknya.

Penjelasan mengenai kegiatan implementasi dari marketing public relations Negarawan akan ditekankan pada soft data berupa kata-kata, bukan melalui data berupa angka atau statistik. Neuman (2014) menekankan soft data berupa kata-kata penting untuk pendekatan kualitatif. Penelitian ini memperoleh pemaparan yang utuh tentang bagaimana strategi marketing public relations Negarawan melalui deskripsi dari sudut pandang informan kunci yang mengetahui secara mendalam merek Negarawan.

Penelitian ini akan menggunakan desain studi kasus. Daymon dan Holloway (2011) menyatakan studi kasus merupakan suatu penelitian yang menggunakan pengamatan mendalam dan menyeluruh. Menurut Yin (2014) metode penelitian studi kasus dapat dipilih sebagai upaya dalam memberi nilai tambah pada pengetahuan tentang fenomena individual, organisasi, sosial dan politik. Studi kasus dipilih karena peneliti melihat metode ini sesuai untuk menjawab rumusan masalah yang ada yaitu bagaimana implementasi dari three ways strategy marketing public relations Negarawan dalam membangun citra merek untuk generasi muda. Keberhasilan Negarawan dalam membangun citra merek dapat dilihat sebagai kasus dan dianalisis melalui implementasi three ways strategy marketing public relations.

Teknik perolehan data diperoleh melalui wawancara dan observasi dan studi kepustakaan dalam bentuk buku, jurnal elektronik, artikel, situs resmi, media sosial, dan hal - hal yang berhubungan dengan obyek penelitian. Data sekunder juga didapatkan melalui artikel, berita, promosi dari media seperti portal berita online, radio, liputan tentang Negarawan. Kemudian metode selanjutnya adalah dokumentasi, yaitu informasi yang diperoleh dari arsip berupa bagan, tulisan, maupun foto hasil olahan pihak lain yang masih berhubungan dengan obyek penenelitian.

Peneliti melakukan wawancara terhadap informan kunci yaitu: AA, Chief Executive Officer, dan MP selaku Chief Marketing Officer di PT. Negarawan international group.

Dalam penelitian ini digunakan empat model pengecekan data triangulasi (Ruslan, 2017), yakni: (1) Triangulasi sumber, karena peneliti tidak hanya mewawancara satu informan kunci, tetapi dua informan kunci; (2) Triangulasi waktu, karena penulis tidak hanya melakukan sekali atau dua kali pengamatan, tetapi selama enam bulan; (3) Triangulasi teori karena peneliti menggunakan berbagai teori dan konsep dari sumber-sumber yang berbeda terkait dengan strategi marketing public relations; (4) Triangulasi metode, karena peneliti tidak hanya melakukan wawancara, namun melakukan observasi partisipatif, serta studi pustaka dan dokumentasi.

\section{HASIL PENELITIAN}

Berdasarkan keterangan informan kunci AA dan MK terkait dengan kegiatan Negarawan selama dua tahun terakhir, diperoleh data tentang penerapan three ways strategy Negarawan, selengkapnya sebagai berikut (Tabel 2): 
Tabel 2. Penerapan three ways strategy Negarawan Sumber: Data Olahan Peneliti, 2020.

\begin{tabular}{|c|c|c|c|}
\hline Strategi & Target/Sasaran & Penerapan & Pernah/Tidak \\
\hline Push strategy & $\begin{array}{l}\text { Sales Force } \\
\text { Dealer } \\
\text { Distributor } \\
\text { Konsumen }\end{array}$ & $\begin{array}{l}\text { Trade show/Expo } \\
\text { Publisitas } \\
\text { Penerbitan katalog } \\
\text { Potongan harga }\end{array}$ & $\begin{array}{l}\text { Pernah } \\
\text { Pernah } \\
\text { Pernah } \\
\text { Pernah }\end{array}$ \\
\hline Pull Strategy & $\begin{array}{l}\text { Konsumen atau pemakai } \\
\text { produk }\end{array}$ & $\begin{array}{l}\text { Media events } \\
\text { Media tours } \\
\text { Story placement } \\
\text { Product placement } \\
\text { Web sites } \\
\text { Sampling } \\
\text { Newsletter } \\
\text { Iklan layanan } \\
\text { masyarakat } \\
\text { Survey }\end{array}$ & $\begin{array}{l}\text { Pernah } \\
\text { Tidak } \\
\text { Tidak } \\
\text { Tidak } \\
\text { Pernah } \\
\text { Tidak } \\
\text { Pernah } \\
\text { Tidak } \\
\text { Pernah }\end{array}$ \\
\hline Pass Strategy & $\begin{array}{l}\text { Pembentukan opini positif } \\
\text { Konsumen melalui } \\
\text { pemerintah LSM/Key } \\
\text { Opinion Leader }\end{array}$ & $\begin{array}{l}\text { Memperhatikan isu } \\
\text { sosial dalam } \\
\text { pelaksanaan bisnis } \\
\text { Aktivitas kepedulian } \\
\text { sosial } \\
\text { Komunikasi } \\
\text { Sponsor }\end{array}$ & $\begin{array}{l}\text { Pernah } \\
\text { Pernah } \\
\text { Pernah }\end{array}$ \\
\hline
\end{tabular}

Berdasarkan observasi dan keterangan kedua informan kunci, Negarawan telah mengimplementasikan push, pull, pass marketing public relations strategy dalam berbagai bentuk kegiatan, meskipun pada pull strategy tidak semua kegiatan dilakukan oleh pihak Negarawan. Hal ini juga menunjukkan dibandingkan strategi lainnya, strategi pull Negarawan merupakan strategi yang lemah karena dari banyaknya kegiatan yang ada Negarawan hanya menjalankan empat kegiatan. Untuk itu peneliti akan membahas mengenai setiap strategi dan implementasi kegiatan yang telah dilakukan oleh Negarawan dalam membangun citra mereknya.

Berdasarkan pemaparan dari kedua informan, Negarawan menggunakan push strategy untuk mendukung direct selling. Penerapan strategi push juga memperhatikan sisi komunikasi atau branding dari merek Negarawan. Hal tersebut dapat diketahui dari pemaparan informan kunci AA, bahwa Negarawan selalu berusaha menyampaikan key message dalam setiap kegiatan push yang dilakukan. Hal ini diperkuat dengan pernyataan informan MK yang mengatakan 20 persen kegiatan push strategy Negarawan adalah branding untuk memperkuat citra.

Salah satu kegiatan push strategy Negarawan adalah Exhibition yang selalu menyampaikan pesan kunci serupa pada kegiatan pameran yang dilakukan, yaitu "tenant ternasionalis". Pesan kunci yang disampaikan merupakan bentuk komunikasi merek untuk membangun citra merek di benak konsumen. Melalui pesan kunci "tenant ternasionalis" di setiap kegiatan exhibition menunjukkan Negarawan selalu ingin berbeda dan tampil lebih dibandingkan merek lainnya, karena umumnya di setiap exhibition yang diikuti Negarawan merupakan pameran bagi merek-merek lokal asli Indonesia. Sebagai salah satu merek lokal asli Indonesia yang juga mengikuti pameran tersebut, Negarawan berusaha untuk hadir sebagai tenant yang ternasionalis.

Penyampaian pesan kunci dalam kegiatan exhibition yang dilakukan Negarawan merupakan usaha untuk menciptakan experience yang berbeda di benak konsumen sehingga akan menciptakan citra merek yang baik di benak konsumen. Berdasarkan pernyataan informan kunci, peneliti menemukan bahwa pesan kunci yang ingin disampaikan tertuang dalam berbagai kegiatan pameran, salah satunya peluncuran produk spesial yang terbatas seperti tas dan peralatan rumah tangga.

Selain itu peneliti juga menemukan berbagai kegiatan yang terintegrasi dalam pameran ini selain peluncuran produk spesial. Negarawan juga memberikan potongan harga, dan mengundang media pada pameran untuk fashion show produk Negarawan. 
Jadi dapat dikatakan, nilai tambah dari kegiatan push strategy Negarawan dalam membentuk citra merek batik untuk generasi muda adalah Negarawan memperhatikan sisi komunikasi merek dengan membuat pesan-pesan kunci pada tiap kegiatan push strategy, terutama pada kegiatan pameran dengan. Pada kegiatan ini, Negarawan melakukan integrasi berbagai kegiatan push strategy seperti potongan harga, penerbitan katalog khusus, serta publisitas dalam satu wadah kegiatan utama yaitu exhibition.

Sisi komunikasi merek pada kegiatan push menciptakan kesan bahwa merek Negarawan berbeda dari batik lainnya. Selain exhibition push strategy yang pernah dijalankan oleh Negarawan adalah Publisitas. Publisitas merupakan produk public relations yang dapat dilihat sebagai salah satu produk komunikasi yang menguntungkan perusahaan. Publisitas umumnya didapatkan secara gratis. Media meliput perusahaan/produk perusahaan secara cuma-cuma karena nilai berita yang dimiliki perusahaan maupun produknya. Negarawan beberapa kali pernah mendapatkan publisitas dari media-media online.

Berdasarkan hasil observasi, Peneliti menemukan publisitas Negarawan ada di media online dan media arus utama seperti Kompas, Koran Jakarta, Viva.com. Artikel yang dikeluarkan oleh media online ini memiliki tone yang positif, umumnya mendukung serta mempromosikan produk Negarawan. Hal ini akan mendukung penjualan dari Negarawan karena publisitasnya menekankan keunikan produk Negarawan sebagai batik untuk generasi muda.

Untuk kegiatan Pull strategy, Negarawan fokus pada beberapa bentuk kegiatan yaitu kerjasama dengan media, penggunaan website dan media sosial, serta adanya electronic news letter. Penggunaan berbagai kegiatan ini sesuai dengan konsep pull strategy dari Harris. Jenis kerjasama dengan media seperti kegiatan contests digunakan untuk meningkatkan partisipasi konsumen dengan merek Negarawan, sehingga masyarakat lebih tertarik mengikuti kegiatan Negarawan karena bentuknya adalah kontes. Selain itu melalui kontes yang berkerjasama dengan media, Negarawan mendapat exposure yang luas.

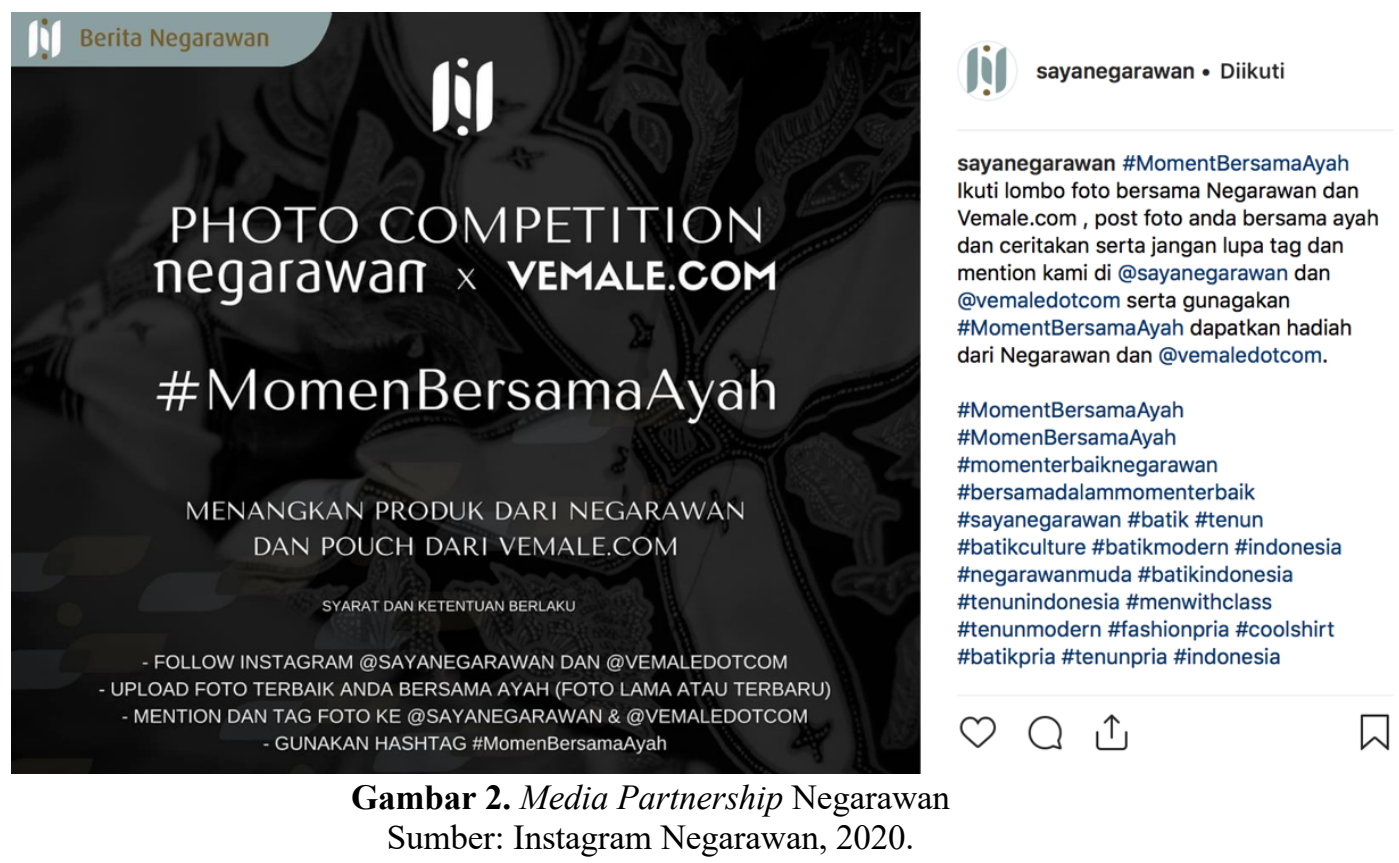

Sementara itu media tour dilakukan untuk meningkatkan exposure Negarawan. Kegiatan media tour juga dilakukan agar media memiliki konten yang lebih menarik melihat langsung bagaimana batik Negarawan diproduksi.

Dalam membuat konten terutama pada pull strategy melalui media partnership (Gambar 2), Negarawan memfokuskan medium dan pesannya, sesuai dengan target mereka yaitu generasi muda. Konten yang sudah jelas targetnya ini membuat pesan lebih mudah disampaikan dan aktivasi kegiatan yang sesuai dengan target generasi muda. Dengan begitu, generasi muda lebih tertarik dengan konten pesan dari Negarawan sehingga di benak konsumen akan tercipta citra merek yang kuat. Pesan yang dibuat sangat jelas ditujukan untuk generasi muda dengan berbagai kegiatan yang sesuai.

Kegiatan pull strategy yang paling berhasil menurut kedua informan kunci adalah media partnership. Hal ini karena terdapat beberapa indikator yang jelas dalam melihat keberhasilan media 
partnership Negarawan dengan berbagai media seperti radio, majalah, dan media online. Pertama, dapat dilihat, jumlah peserta yang terus meningkat dalam kegiatan kontes yang berkerjasama dengan media. Kedua, traffic website dan media sosial Negarawan meningkat karena buzz yang tercipta dari kegiatan kontes dengan media sosial.

Pengikut Negarawan di media sosial Instagram hingga saat bisa berjumlah lebih dari 24 ribu orang. Menurut informan MK, salah satu penyebabnya adalah buzz yang tercipta dari kontes yang berkolaborasi dengan media. Terciptanya buzz di media sosial hasil dari media partnership Negarawan sesuai dengan tujuan dari marketing public relations dari Harris (2006):

Its primary purpose is to achieve third-party endorsement from key customer influencers, such as the news media. ... MPR also works to create word-of-mouth "buzz" about the brand by generating news about the product and its features, ...

Melalui media partnership, Negarawan menciptakan kontes dan media tours yang menghasilkan news value sehingga tercipta buzz. Banyak orang membicarakan Negarawan di media sosial karena hasil dari kontes dan liputan media terhadap Negarawan. Untuk menciptakan citra merek Negarawan untuk generasi muda, Negarawan memilih media yang target audience-nya generasi muda dan menjalin kerjasama dengan media yang pendengarnya anak muda seperti Prambors. Hal itu berhasil menciptakan asosiasi bahwa Negarawan adalah merek yang hadir untuk generasi muda.

Dalam implementasi pass strategy, peneliti melihat kegiatan Negarawan untuk menciptakan citra merek yang baik di benak publik dalam mendukung operasional perusahaan. Seperti dipaparkan sebelumnya, Negarawan adalah perusahaan yang menyediakan batik serta tenun premium bagi generasi muda. Negarawan ingin agar generasi muda bangga menggunakan produk budaya hasil karya Indonesia karena saat ini keperdulian generasi muda terhadap budaya khususnya batik terus menurun. Tentu saja keperdulian Negarawan terhadap ketertarikan generasi muda pada budaya Batik akan mempengaruhi kegiatan operasional bisnis Negarawan.

Kegiatan bisnis Negarawan berusaha untuk menumbuhkan kecintaan generasi muda dengan budaya batik. Hal inilah yang membuat kegiatan bisnis Negarawan menjadi salah satu bentuk pass strategy. Dari awal, Negarawan bukanlah merek yang hanya mencari keuntungan semata namun juga perduli pada budaya batik dan berusaha mempertahankan budaya batik.

Berdasarkan wawancara dengan kedua informan kunci, diketahui Negarawan menjalankan pass strategy melalui beberapa jenis kegiatan. Peneliti menemukan, kegiatan bisnis yang dijalankan Negarawan tercermin pada pass strategy dalam bentuk keperdulian dalam mempertahankan budaya batik. Kedua informan kunci memiliki pandangan yang sama bahwa Negarawan hadir salah satunya untuk mempertahankan budaya batik dan untuk memajukan industri batik secara keseluruhan.

Keperdulian founder Negarawan terhadap budaya batik dan keinginan untuk memajukan usaha batik secara keseluruhan tercermin dari setiap kegiatan bisnisnya. Kegiatan inilah yang akan dilihat oleh masyarakat sehingga terbentuk di benak konsumen bahwa Negarawan adalah merek batik yang tidak hanya mencari keuntungan.

Sebagai bentuk kegiatan pass strategy, Negarawan juga menjalankan aktifitas keperdulian sosial. Salah satu isu utama yang diangkat adalah masalah kesehatan, terutama masalah kanker payudara. Negarawan juga pernah mengangkat isu kesejahteraan desa dengan membantu membersihkan desa batik di daerah Pekalongan, Jawa Tengah. Kegiatan ini adalah kolaborasi dengan Gojek Indonesia.

Sekali lagi kolaborasi dengan merek besar yang merupakan produk anak bangsa menunjukkan, Negarawan ingin menciptakan persepsi di benak konsumen bahwa untuk menyelesaikan suatu isu sosial Negarawan terbuka untuk kerjasama dengan merek lainnya. Selain itu melalui kegiatan ini Negarawan menunjukkan bahwa Negarawan perduli pada kesejahteraan pihak yang membantu bisnis Negarawan.

Melalui jawaban dari dua informan kunci, penulis menemukan bahwa kegiatan pass strategy yang paling berhasil adalah Sponsor. Hal ini karena terdapat beberapa hal yang dicapai Negarawan ketika mensponsori influencers. Pertama, yang didapat adalah opini positif karena Negarawan membantu keberhasilan suatu acara maupun hasil dari review positif influencers. Kedua, ketika Negarawan mensponsori acara seperti Abang \& None dan Kang \& Nong, Negarawan kembali mendapatkan publikasi dari media. Ketiga terjadinya word-of-mouth yang positif terhadap merek Negarawan.

Berdasarkan observasi yang dilakukan, peneliti menemukan dengan mensponsori influencers seperti Barasuara dan Pandji, Negarawan mendapatkan endorsement dari para influencer tersebut yang 
memperkuat posisi Negarawan di benak konsumen (Gambar 3). Konsep endorsement dijelaskan oleh Harris: "Endorsement is helpful to brand building, endorsement support market positioning and make a news for brand" (Harris, 2006).

Endorsement merupakan suatu kegiatan dengan public figure memberikan dukungan terhadap suatu merek untuk memperkuat merek tersebut di masyarakat. Pandji mempromosikan Negarawan pada media sosialnya yang jumlah pengikutnya 1,1 juta pengguna. Promosi dari Pandji yang jujur memperkuat posisi brand Negarawan di benak para pengikut Pandji. Selain itu dari sponsor Barasuara, Negarawan mendapatkan publikasi di media online besar seperti Kompas yang membuat masyarakat aware dan memiliki citra positif terhadap merek Negarawan.

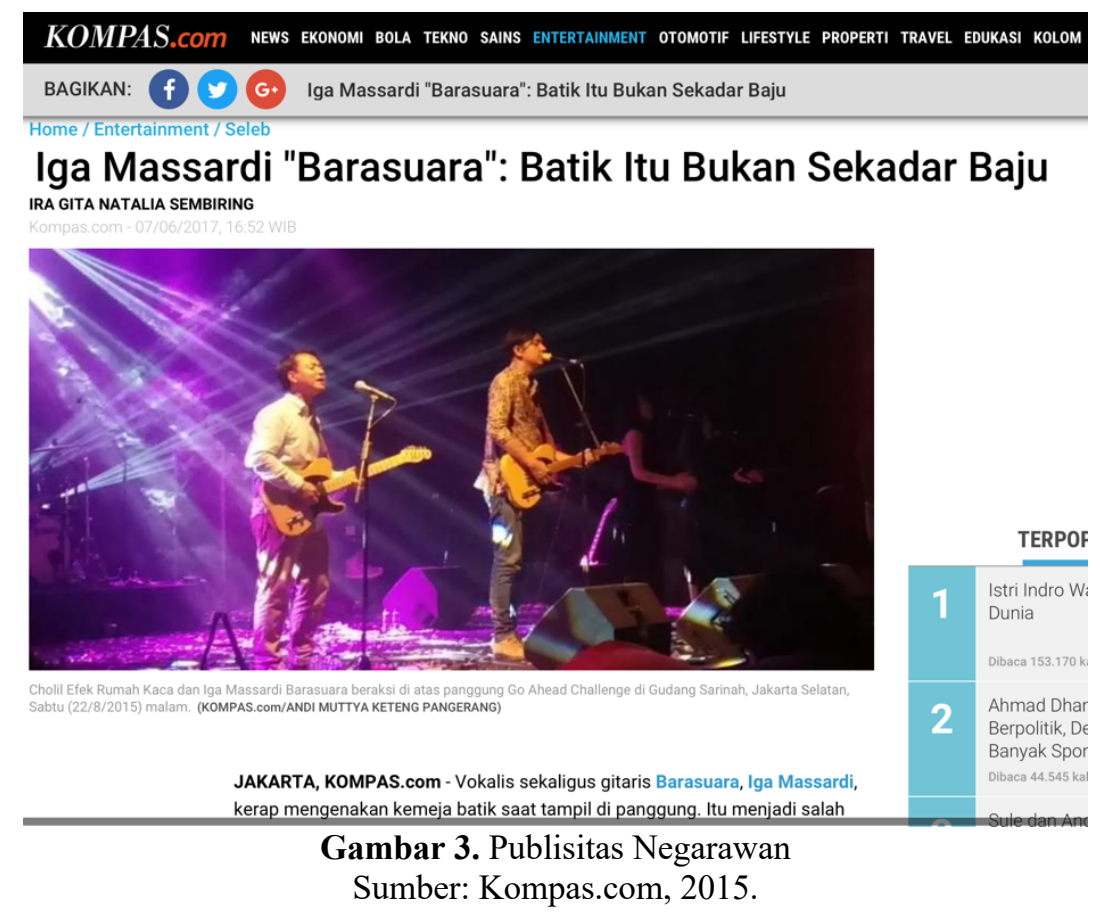

\section{KESIMPULAN}

Dalam menjawab rumusan masalah peneliti menggunakan konsep three ways strategy yang dipaparkan oleh Harris (2006) dan juga oleh Alifhami (2008). Konsep three ways strategy marketing public relations terdiri dari 3 strategi besar push, pull, pass yang di setiap strategi memiliki kegiatan masing-masing dan telah dijalankan Negarawan serta saling mendukung satu sama lain.

Dalam push strategy Negarawan menggunakan push strategy marketing public relations untuk mendukung direct selling. Penerapan strategi push dari Negarawan memperhatikan sisi komunikasi atau branding dari merek Negarawan. Dari sisi komunikasi merek membuat push strategy marketing public relations Negarawan dapat membentuk citra merek batik untuk generasi muda.

Kegiatan pull strategy yang paling berhasil dari Negarawan adalah media partnership yang menekankan pada partisipasi konsumen sehingga konsumen bisa merasa dekat dengan merek Negarawan. Pass strategy Negarawan merupakan strategi terkuat yang dimiliki Negarawan yang dijalankan melalui aktifitas keperdulian sosial, bisnis yang memperhatikan isu sosial, sponsor, dan kegiatan lainnya untuk menciptakan opini publik positif terhadap merek Negarawan.

\section{DAFTAR PUSTAKA}

Alifahmi, H. (2008). Marketing Communication Orchestra. Bandung: Examedia.

Daymon, C., Holloway, I. (2011). Qualitative Research Methods in Public Relations and Marketing Communications $\left(2^{\text {nd }} E d\right)$. New York: Routledge.

Harris, T. L. (1998). Value Added Public Relations. New York: McGraw-Hill.

Harris, T.T., Whalen, T.P. (2006). The Marketer's Guide to Public Relations in the 21st Century. Ohio:

Thomson. 
Leavy, P. (2017). Research Design Quantitative, Qualitative, Mixed Methods, Arts-Based, and Community-Based Participatory Research Approaches. New York: The Guilford Press.

Muhammad, R. (2018) Perancangan Digital Campaign Sebagai Strategi Peningkatan Awareness terhadap Batik Betawi. (Skripsi yang tidak dipublikasikan). Institut Seni Indonesia Yogyakarta.

Neuman, L.W. (2014). Social Research Methods: Qualitative and Quantitative Approaches $\left(7^{\text {th }}\right.$ Ed). Edinburg: Pearson.

Oktavia, Y., S. (2017). Perancangan Promosi untuk Memperkenalkan Batik Betawi kepada Generasi Dewasa Muda. (Skripsi yang tidak dipublikasikan). Universitas Kristen Maranatha

Rakhmawati, Y. (2019). Buku Ajar Metode Penelitian Komunikasi. Surabaya: Putra Media Nusantara.

Ruslan, R. (2017). Metode Penelitian Public Relations dan komunikasi. Jakarta: PT. Raja Grafindo Persada.

Sanjaya, F. \& Yuwanto L. (2019). Budata Berbusana Batik pada Generasi Muda. Mediapsi. 5(2), 8896

Subekti, P., Hafiar, H. \& Komariah, K. (2020). Word of Mouth Sebagai Upaya Promosi Batik Sumedang Oleh Perajin Batik (Studi Kasus pada Sanggar Batik Umimay). Dinamika Kerajinan dan Batik: Majalah Ilmiah, 37(1), 41-54)

UNESCO, Decision of the Intergovernmental Comitteee: 4.COM 13.44. Retrieved on https://ich.unesco.org/en/decisions/4.COM/13.44

Yin, R.K. (2014). Case Study Research Design and Methods ( $5^{\text {th }}$ Ed). Thousand Oaks, CA: SAGE.

Yudhi, L. (2019). Batik Tulis Sebagai Warisan Budaya Dunia Dalam Menanamkan Rasa Cinta Tanah Air Generasi Muda Indonesia. Commed: Jurnal Komunikasi Dan Media, 4(1), 01-15. doi:10.33884/commed.v4i1.1297 